У, $А$ K 342.7:316.37

ББК $67.400 .3+60.53$

DOI 10.22394/1682-2358-2018-5-138-143

V.N. Lupandin, Candidate of Sciences (Politics), Docent of the History and International Relations Department, Central Russian Institute of Management, Branch of the Russian Presidential Academy of National Economy and Public Administration

E.V. Titova, Candidate of Sciences (Sociology), Docent of the Labor Law and Social Security Department, Central Russian Institute of Management, Branch of the Russian Presidential Academy of National Economy and Public Administration

\section{CONSTITUTIONAL AND LEGAL BASIS OF THE SOCIAL STATUS OF RUSSIAN YOUTH}

A complex analysis of the social status of modern Russian youth from the position of the constitutional law of Russia is drawn. The authors investigate the background of the young generation as a sociodemographic group, its age characteristics, the specifics of social status and social role. The specific social status and social role of young Russians in society is attributed to the peculiarities of law enforcement in their relation, primarily, the realization of their rights and freedoms provided by the Constitution of the Russian Federation.

Key words and word-combinations: youth, social status of young people, legal status of young people.
В.Н. Мупандин, кандидат политических наук, дочент кафедри истории и международныхх отночений Среднерусского института упраһления - филиала Российской академии народного хозяйства и государственной службь при Президенте РФ (email: vit183@yandex.ru)

E.B. Титова, кандидат сочиологиеских наук, доцент кафедрь трудового права и соииального обеспечения Среднерусского института управления - филиала Российской академии народного хозяйства и государственной службь при Президенте РФ (email: ogau@mail.ru)

\section{КОНСТИТУЩИОННО- ПРАВОВЫЕ ОСНОВЫ СОЩИААЬНОГО СТАТУСА РОССИЙСКОЙ МОАОАЕЖИ}

\footnotetext{
Аннотация. Проводится комплексный анализ социального статуса современной российской молодежи с позиции конституционного права России. Исследуются предпосылки оформления молодого поколения как социально-демографической группы, ее возрастные характеристики, специфика социального статуса и социальной роли. Исследуются вопросы реализации прав и свобод молодежи, прописанные в Конституции РФ.

Ключевые слова и словосочетания: молодежь, социальный статус молодежи, правовой статус молодежи.

B современных отечественных и зарубежных соџиально-гуманитарных исследованиях отмечается устойчивый интерес к молодежной проблематике. Этот интерес не случаен, поскольку молодые мюАи игра-
} 
ют в обществе значимую роль, выступают активным началом общественного развития, опредемяют его направление и конечный результат.

Как соџиальная группа молодежь начала рассматриваться на рубеже XIXХХ вв. в индустриальных обществах, до этого периода, на каждой стадии социально-исторического общества в силу объективных причин молодость как самостоятельный этап жизнедеятельности человека, не выдемялась: во-первых, средняя продолжительность жизни мюдей длительное время была относительно невелика; во-вторых, условия и образ жизни мюдей во многом способствовали их переходу из стадии детства сразу в стадию взрослости. Коренным образом ситуация изменилась во второй половине XIX в.: с одной стороны, начала увеличиваться общая продолжительность жизни мюдей, а с Аругой - начавшееся развитие промышленности привело к тому, что увекичилась общая прОАОАжитеАьность ПОАГОтовки ИндивиАа к трудовой деятеАьности. Все это в совокупности способствовало более позАнему началу трудовой деятельности и самостоятельной жизни человека. МежАу детством и взрослостью возник промежуточный этап жизненного цикла - молодость и соответствуюшая ему соџиальная группа - молодежь.

Согласно определению, молодость - это промежкуточный этап между детством и взрослостью, который в биологическом аспекте характеризует завершение помового созревания индивида, а в социальном - необходимость его жизненного самоопределения и обретения самостоятельности $[1$, с. 105]. В свою очередь, мо-

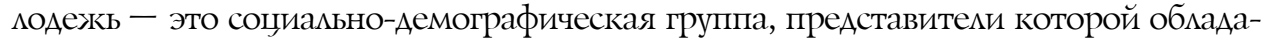
ют определенными возрастными границами, психологическими особенностями, специфическим социальным статусом и соџиальной ролью [2, с. 476] .

Аостаточно часто с понятием «молодежљ» соотносится понятие «молодое поколение». В широком смысле поколение - это общность определенных объектов по Алине цепи непосреАственных предков до некоторого родоначальника или же по времени рождения [3, с. 10-11] . В соџиальных науках покомение чаше всего опредемяется как общность чменов общества по дате рождения, а его представители характеризуются сходными периодами прохождения основных этапов жизненного цикла [3, с. 10-11]. В то же время поколение может рассматриваться как совокупность индивидов, которые явцяются свиАетемями и участниками определенных исторических событий. Следовательно, в отношенИи молОАОГО поколения можно, с одной стороны, говорить О возрастном критерии его формирования, а с Аругой - об историческом.

Аля молодежи, как соџиально-демографической группы, характерны специфический соџиальный статус и соџиальная роль. Соџиальный статус момодежи - это положение, занимаемое молодежью в системе общественных отношений $[4$, с. 109]. Социальная роль - это совокупность действий, которые должен выполнить человек, занимающий данный статус. Иными словами, социальная роль - это «поведение, которое ожидается от человека, занимающего определенный соџиальный статус) [5, с. 237].

Наличие у молодежи соџиального статуса и соџиальной роли обусловлено смедуюшими факторами:

молодежь - это часть общества (его социальных классов и слоев), продукт их развития и среАство воспроизводства; 
молодежкь - это явмение конкретно-историческое, она выступает продуктом истории и культуры, Авижущей силой и необходимым условием перемен;

молодежь как соџиально-демографическая группа находится в положении зависимости, не имея самостоятельности в принятии решений [2, с. 480-481] .

Исторически сложкившимися задачами молодежки, во многом определяющими специфику ее социального статуса, явцяются следующие:

завершение полового созревания, формирование способности продолжения рода, создание семьи;

получение общего и профессионального образования, выбор профессии, подготовка к трудовой деятельности;

завершение социализации, интеграция в систему общественных отношений; обретение самостоятельности при сохранении взаимоотношений с родителями.

Специфика социального статуса молодежи проявцяется в его неопределенности (с одной стороны, молодые мюди - это уже не Аети, а с Аругой - они еще не взрослые, обладающие всей полнотой прав и обязанностей) и во многом связана со спецификой ее правового статуса. Правовой статус - это установленное нормами права положение его субъектов, совокупность их прав и обязанностей [6, с. 284]. Выдемяют конституџионно-правовой статус, гражданско-правовой статус, административно-правовой статус и т.А. В свою очередь, норма права - это общеобязательное дия всех правило поведения, установленное или санкционированное государством и охраняемое его симой [7, с. 146]. В отечественном праве структурными элементами правового статуса считаются: правосубъектность (правоспособность, дееспособность и деликтоспособность субъекта); установиенные законом права и обязанности; гарантии установценных прав; ответственность субъекта за неисполнение обязанностей [8, с. 560-561]. В соответствии с отечественным законодательством субъектами права, обладающими определенным правовым статусом, явцяются физические или юридические миџа, а отношения, возникающие межАу ними, называются правоотношениями.

В связи с этим актуализируется необходимость ответим на следующие вопросы: Обладает ми российская молодежь собственным правовым статусом; каковы конституционно-правовые основы социального статуса молодежк России? Отвечая на первый вопрос, следует отметить, что важнейшей характеристикой молодежи, опредемяющей спещифику ее участия в общественных отношениях и специфику ее правоотношений, является возраст молодых инАивидов и возрастные граниџы молодости. Нижняя возрастная граниџа моло-

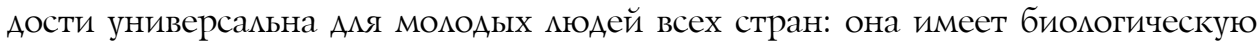
природу и связана с завершением физиологического (полового) созревания человека. Согласно данным ООН, нижняя возрастная граница молодости составцяет 13-14 мет, аналогичное значение Амя нижней возрастной границы молодости принято в отношении российской молодежи. В свою очереАь, верхняя возрастная граниџа молодости не может быть универсальной, поскольку имеет соџиальную природу и связана с полной самостоятельностью и независимостью молодых мюдей от родителей. Согласно данным ООН, верхняя граница молодости должна определяться на уровне 29-30 лет. Аналогичное значение верхней возрастной граниџы молодости законодательно принято и в России [9] . 
В пределах возрастных границ молодости следует ввести понятия «совершеннолетие» и «несовершеннолетие». Совершеннолетие - это возраст (в России с 18 мет), с достижением которого наступает полная гражданская дееспособность, то есть способность мица своими действиями приобретать и осуществлять права и обязанности. Соответственно, мица, достигшие совершеннолетия, определяются как совершеннолетние, а не достигшие - как несовершеннолетние. Несовершеннолетние мица в особых случаях, при наличии особых обстоятельств с установценного законом возраста могут становиться дееспособными. В то же время, они не имеют права голосовать, усыновцять, опекать детей и т.п.

Совершеннолетие, имеющее важное значение в системе права, позволяет подразделить молодое поколение на две группы: с 13 до 18 мет - несовершеннолетние, обладающие частичной дееспособностью, а значит не имеющие собственного правового статуса; и с 18 до 30 мет - совершеннолетние, обладающие полной дееспособностью, а значит имеющие собственный правовой статус. Получается что, с позиџии соџиологических наук правовой статус Аолжна иметь часть молодого поколения в возрасте от 18 до 30 мет, а с позиции юридических наук молодежь не может иметь собственного правового статуса. В отличие от социологии в отечественной юриспруденции понятие «молодежкњ явцяется

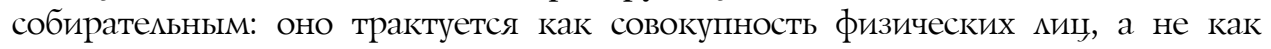
единая соџиальная группа. Во многом из-за этого в отечественном праве заявмяется, что понятие «правовой статус молодежки есть понятие неопределенное, поскольку субъектом правоотношения в этом случае выступает юридически неопределенное миџо. Из-за этого же в отечественном праве отсутствуют специфические нормы, которыми руководствуются исключительно в отношении молодежи. Следовательно, в контексте данной публикации понятие «правовой статус молодежи» необходимо рассматривать скорее не с юридической, а с социологической точки зрения, а в отношении молодых индивидов говорить не об особом правовом статусе, а об особом порядке правоприменения.

Отвечая на второй вопрос, подчеркнем, что анализировать конституционно-правовые основы социального статуса российской молодежки (исходя из особенностей трактовки понятия «молодежь» в отечественном праве) следует в рамках главы 2 Конститущии Российской Федерации. В частности, в ст. 60 Аанной главы прописано, что все совершеннолетние граждане России могут самостоятельно осуществцять свои права и обязанности начиная с 18 мет [10] . Это означает, что каждый совершеннолетний гражданин России обладает полной общей правосубъектностью, а значит надемяется определенными правами и обязанностями. Полный перечень прав кажАого молодого россиянина можно проследить в ст. 17-56 главы 2 Конститущии РФ [10]. Вместе с тем права и свободы Молодых россиян Аополняются определенными обязанностями, которые отражкены в ст. 57-59 главы 2 Конституции РФ [10] .

Анализ прав, свобод и обязанностей, которыми наделяется российская момодежь согласно Конституции РФ, позволяет выделить сферы, в которых проявцяется спеџифика соџиацьного статуса молодых россиян: образовательная, профессиональная, политическая и семейная.

ОАной из основных задач молодежки, определяющих спещифику ее сощиального статуса, явцяется получение общего и профессионацьного образования, 
выбор профессии, подготовка к трудовой деятельности. Эта задача решается в рамках образовательной и профессионацьной сфер. В ч. 2 ст. 43 Конституции РФ прописаны гарантии общедоступности и беспиатности общего и среднего профессионального образования в государственных или муниципальных образовательных учреждениях [10]; в ч. 3 ст. 3 закреплено право каждого гражАанина России на конкурсной основе бесплатно получить высшее профессиональное образование в государственном ици муниципацьном образовательном учреждении [10]. ОАнако реальность свидетельствует о том, что эти положения Конституџии РФ соблюдаются не в полной мере: во-первых, не все образовательные учрежкения среднего профессионального образования в России предоставцяют услуги бесплатного образования; во-вторых, уменьшается число бюджетных мест в образовательных учреждениях высшего профессионального образования; в-третьих, регуцярно увеличивается стоимость получения профессионацьного образования всех уровней. Все это в совокупности приводит к возникновению следующих негативных тенденџий в молодежной среАе:

- достаточно часто молодой россиянин вынужден получать профессиональное образование не в соответствии со своими интересами, потребностями и возможностями, а в соответствии с возможностями его и его роАитиелей осуществцять оплату профессионацьного обучения;

- получение профессионального образования по определенному направлению подготовки не гарантирует того, что выпускник будет в будущем работать в соответствии с полученной квалификацией;

- даже если выпускник будет работать в соответствии с полученной квамификацией, велика вероятность разочарования в профессии, смена рода профессионацьной деятельности.

Сложная и противоречивая ситуация складывается в профессиональной сфере. С оАной стороны, Конституция РФ декларирует право российской моцодежи на свободный трУА без принужАения (ст. 37 Конституџии РФ) [1]; с Аругой - кажАый молодой россиянин, имея на руках Аокумент о получении профессионального образования, сталкивается с рядом трудностей, как в проџессе трудоустройства, так и в проџессе выполнения профессиональных обязанностей. Во-первых, многие работодатели, явцяясь индивидуальными предпринимателями, в качестве одного из критериев трудоустройства упоминают наличие опыта работы у выпускника. Получить данный опыт, обучаясь на Аневной форме, проблематично. Во-вторых, в качестве одного из критериев трудоустройства часто упоминается нацичие Аиплома о высшем профессиональном образовании, что не всегда обоснованно. В-третьих, у работодателей нередко возникает недопонимание межку уровнями полученного высшего профессионального образования, например, специалистом, бакалавром и магистром, что создает проблемы при трудоустройстве.

Перечень таких трудностей можно продолжить, а их анализ должен стать темой отдельного специального исследования, но в совокупности они приводят к развитию феномена, который в соџиологии обозначается «феномен работающего студента». В этом феномене есть свои пиюсы и минусы Амя момодого поколения, но, на наш взгляА, попытка сочетать обучение и трудовую деятельность снижает эффективность обоих проџессов. 
Проблемы, возникающие у российской молодежи в образовательной и профессиональной сфере, не могут не влиять на реализаџию других задач, характерных для молодого поколения. Например, нельзя обрести экономическую самостоятельность и независимость от родителей, не имея квалификаџии, стабильной работы и заработка. Затруднительно также создание собственной семьи и рождение детей, вследствие чего в реальности отмечается увеличение возраста вступления в брак, увеличение возраста рождения первого ребенка и т.п. Меняется и отношение российской молодежи к браку и семье, однако это уже пробцема ценностной ориентаџии молодых мюдей, их морально-нравственных качеств, но не проблема права.

В политической сфере трудностей не меньше. Несмотря на то что в Конституции РФ прописано право молодых россиян на создание политических объединений, на право избирать и быть избранными, на деле существует множество препятствий и ограничений, способствующих отчуждению молодежи от политики, возникновению политического абсентеизма в молодежной среде.

Таким образом, можно сделать вывод: Аля того, чтобы российская молоАежь в полной мере реализовывала возможенные на нее задачи в соответствии с ее соџиальным статусом, необходима выработка в соответствии с российским законодательством комплексных мер помощи соџиума Аля успешной интеграции молодежи в систему обшественных отношений, что значит предполагает разработку и реализацию детально проработанной молодежной политики дмя всех подкатегорий молодежи. В основе данных мер Аолжна быть Конституция РФ и конституционное право страны.

\section{Библиографический список}

1. Волков Ю.Г. Социология молодежи: учебное пособи. / под ред. Ю.Г. Волкова. Ростов н/Д., 2001.

2. Социология молодежи: Энциклопедический словарь / отв. ред. Ю.А. Зубок, В.И. Чупров. М., 2008.

3. Власова О.И. Молодое поколение современной России: устойчивость и изменчивость трудовой деятельности как факторы структурирования: дис. ... канд. социол. наук. Екатеринбург, 2014.

4. Ильинский И.М. Молодежь и молодежная политика: философия, история, теория. М., 2001.

5. Громов И.А., Семенов В.А. Западная социология: в 2 ч. М., 2018. Ч. 2.

6. Касьянов В.В., Нечипуренко В.Н. Социология права. М., 2018.

7. Морозова Л.А. Теория государства и права. М., 2010.

8. Борисов А.Б. Большой юридический словарь. М., 2010.

9. Об основных направлениях государственной молодежной политики в Российской Федерации: постановление Верховного Совета РФ от 3 июня 1993 г. № 5090-1 // Ведомости СНД и ВС РФ. 1993. № 25. Ст. 903.

10. Конституция Российской Федерации // С3 РФ. 2014. № 31. Ст. 4398.

11. Об общественных объединениях: Федер. закон от 19 мая 1995 г. № 82-Ф3 (в ред. от 20 дек. 2017 г.) // СЗ РФ. 1995. № 31. Ст. 1930; СЗ РФ. 2017. № 52 (Ч. І). Ст. 7927.

12. О государственной поддержке молодежных и детских общественных объединений: Федер. закон от 28 июня 1995 г. № 98-Ф3 (в ред. от 28 дек. 2016 г.) // СЗ РФ. 1995. № 27. Ст. 2503; СЗ РФ. 2017. № 1 (Ч. І). Ст. 19. 